\title{
PENGARUH PEER EDUCATION TERHADAP PENGETAHUAN DAN SIKAP REMAJA TENTANG PENCEGAHAN HIV-AIDS DI SMK KORPRI MAJALENGKA
}

\author{
Ruri Yuni Astari, Eri Fitriyani \\ STIKes YPIB Majalengka \\ ruri_ya@yahoo.co.id
}

\begin{abstract}
Abstrak
Kasus HIV/AIDS di Kabupaten Majalengka setiap tahun meningkat, pada tahun 20012015 ada 114 kasus, terjadi peningkatan 153 kasus pada tahun 2017 menjadi 267 kasus. Salah satu pendekatan pendidikan kesehatan yang efektif pada remaja untuk mencegah maraknya kasus HIV/AIDS yaitu dengan metode Peer Education (pendidikan sebaya). Penelitian ini bertujuan untuk mengetahui pengaruh peer education terhadap pengetahuan dan sikap remaja tentang pencegahan HIV-AIDS di SMK Korpri Majalengka. Penelitian ini menggunakan preexperiment dengan pendekatan one group pretest-posttest design. Populasinya adalah siswa kelas I di SMK Korpri jumlah sampel 83 siswa dengan teknik consecutive sampling. Analisis data menggunakan analisis univariat dengan distribusi frekuensi dan analisis bivariat dengan uji t-berpasangan. Hasil penelitian pengetahuan menunjukkan sebagian kecil $(19,3 \%)$ remaja sebelum peer education berpengetahuan baik dan lebih dari setengahnya $(61,4 \%)$ remaja sesudah peer education berpengetahuan baik. Hasil penelitian sikap menunjukkan kurang dari setengahnya $(43,3 \%)$ sikap remaja sebelum peer education positif dan lebih dari setengahnya $(55,4 \%)$ sikap remaja sesudah peer education positif. Terdapat pengaruh peer education terhadap pengetahuan dan sikap remaja tentang pencegahan HIV-AIDS . Pentingnya pihak sekolah untuk mengoptimalkan OSIS dengan mengadakan seminar, diskusi remaja dengan metode peer education di bawah bimbingan guru BK serta perlunya memanfaatkan mading untuk penyebarluasan informasi tentang pencegahan HIV/AIDS pada remaja.
\end{abstract}

Kata Kunci: Peer Education, Pengetahuan, Sikap, HIV/AIDS

\section{Pendahuluan}

Kesehatan reproduksi remaja didefinisikan sebagai suatu keadaan sehat jasmani, psikologis, dan sosial yang berhubungan dengan fungsi dan proses sistem reproduksi pada remaja. Pada masa ini seorang anak mengalami kematangan biologis sehingga dapat menempatkan remaja pada kondisi yang rawan bila mereka tidak dibekali dengan informasi yang benar mengenai proses reproduksi termasuk tertular penyakit yang berbahaya seperti HIV (Human Immunodeficiency
Virus) yang dapat menyebabkan AIDS (Kemenkes RI, 2018)(Kementerian Kesehatan RI., 2017). Menurut laporan World Health Organization (WHO) pada tahun 2015 menyebutkan bahwa di antara 38 juta orang yang hidup dengan HIV itu ada 18 juta perempuan dan 1,8 juta anak berusia kurang dari 15 tahun (World Health Organization, 2016), (UNAIDS, 2012).

Kasus HIV/AIDS di Propinsi Jawa Barat tahun 2014 - 2016 cenderung mengalami kenaikan, pada tahun 2014 ditemukan kasus baru HIV 28,8\% meningkat menjadi 42,2\% kasus baru HIV. 
JURNAL ILMU KESEHATAN BHAKTI HUSADA:

HeALth SCIENCES JouRnal, Vol. 10 No. 02, DeSEMBer 2019 DOI: $10.34305 / J I K B H . V 10 I 2.93$

Sedangkan kasus AIDS pada tahun 2014 dilaporkan sebanyak 5,54\% dan meningkat sebanyak 59,7\% kasus (Kementerian Kesehatan RI., 2017). Berdasarkan data Dinas Kesehatan Kabupaten Majalengka tahun 2017, sebaran kasus HIV/AIDS di Kabupaten Majalengka dari tahun 2001 hingga September 2017 sebanyak 267 kasus. Kecamatan Cigasong termasuk salah satu kecamatan dengan jumlah kasus HIV yang cukup banyak di Kabupaten Majalengka dari tahun 2001 sampai dengan tahun 2016 tercatat jumlah kasus HIV di Kecamatan Cigasong sebanyak 18 kasus dan AIDS sebanyak 4 kasus dengan jumlah kematian karena HIV/AIDS sebanyak 1 kasus (Dinas Kesehatan Majalengka, 2017).

Upaya preventif untuk mencegah semakin tingginya kasus HIV/AIDS dapat dilakukan dengan cara memberikan pendidikan kesehatan pada remaja tentang HIV/AIDS. Hal ini karena remaja merupakan kelompok yang paling rentan terhadap infeksi HIV/AIDS dan menjadi fokus dari semua strategi penanggulangan penyebaran virus HIV/AIDS (Kusmiran, 2011). Melalui penyebaran informasi dan pendidikan kesehatan tentang HIV/AIDS pada remaja terbukti efektif dalam meningkatkan pengetahuan serta mempengaruhi sikap remaja berisiko terhadap terjangkitnya oleh virus HIV/AIDS (Notoadmodjo, 2012).

Salah satu pendekatan pendidikan kesehatan yang efektif pada remaja untuk mencegah maraknya kasus HIV/AIDS yaitu dengan metode Peer Education (pendidikan sebaya). Peer education adalah suatu prinsip yang bekerja dari remaja, untuk remaja, dan oleh remaja sehingga program peer education (dengan teknik peer educator sebagai aktornya) sangat efektif untuk mendorong keterlibatan remaja dalam pembinaan terhadap temannya sendiri (Mubarok, 2013). Blankhart (2002) menyatakan bahwa peer education merupakan metode pendidikan yang bermanfaat karena dapat merubah perilaku menjadi baik melalui teknik alih pengetahuan yang dilakukan antara
Ciptaan disebarluaskan di bawah Lisensi Creative Commons AtribusiNonKomersial-BerbagiSerupa 4.0 Internasional.

kelompok sebaya, dikarenakan mereka mempunyai hubungan yang lebih akrab, penggunaan bahasa yang sama serta dapat dilakukan dimana saja dan kapan saja dengan cara penyampaian yang santai, lebih nyaman saat berdiskusi tentang permasalahan yang dihadapi termasuk masalah yang sensitif. Peer education dapat menjembatani kesenjangan antara pengetahuan, sikap dan tingkah laku kesehatan dan pendidikan kesehatan, memotivasi seseorang untuk menerima informasi kesehatan serta berbuat sesuai dengan informasi tersebut agar mereka menjadi lebih tahu dan bersikap lebih positif dan diharapkan terbinanya kelompok-kelompok motivator penanggulangan HIV/ AIDS di kalangan remaja (Maulana, 2013), (Andrews, 2011)

Hasil penelitian (Dewi, 2012) menujukkan bahwa pendidikan kesehatan dengan metode peer education sangat efektif untuk meningkatkan pengetahuan dan sikap, ada perbedaan pengetahuan dan sikap pada kelompok yang diberikan pendidikan kesehatan dengan kelompok yang tidak diberikan pendidikan kesehatan. Penelitian yang lain di Univeritas Sumatera Utara menunjukkan bahwa kelompok peer education lebih efektif dan dapat memberi pengaruh pada peningkatan pengetahuan dan sikap mahasiswa dalam upaya menanggulangi HIV/AIDS (Harahap, 2014). Model pembelajaran yang diterapkan dalam pendidikan sebaya adalah komunikasi, informasi, dan edukasi (KIE). Pendidikan sebaya diidentifikasi sebagai sarana penting menyebarkan informasi tentang HIV/AIDS dan kesehatan reproduksi karena terkait masalah seks sering sulit untuk membahas secara terbuka dan adanya hambatan untuk menyampaikan secara formal pendidikan kesehatan reproduksi di sekolah. Pendidikan sebaya dapat mengatasi beberapa kesulitan, dapat mentransfer pengetahuan dan komunikasi dilakukan lebih bebas dan secara terbuka dalam kelompok sebaya (Hidayat, 2012).

SMK Korpri Majalengka yang terletak di Kecamatan Cigasong merupakan 
JURNAL ILMU KESEHATAN BHAKTI HUSADA:

HeALth SCIENCES JouRnal, Vol. 10 No. 02, DeSEMBer 2019 DOI: $10.34305 / J I K B H . V 10 I 2.93$

salah satu sekolah favorit di Kabupaten Majalengka dengan jumlah siswa yang cukup banyak yaitu mencapai 1.678 siswa dan sampai saat belum ditemukan adanya kasus HIV. SMK Korpri Majalengka termasuk sekolah dengan tingkat kedisiplinan yang tinggi dengan banyak prestasi yang diraih setiap tahunnya terutama dalam kejuaraan olah raga. Meskipun demikian, sejumlah kasus kenakalan remaja sering terjadi di SMK Korpri seperti minuman keras, perkelahian dan pergaulan bebas di kalangan remaja (SMK Korpri Majalengka, 2017). Pentingnya memberikan pendidikan kesehatan melalui metode peer education, maka peneliti ingin melakukan penelitian mengenai "Pengaruh Peer Education Terhadap Pengetahuan dan Sikap Remaja Tentang Pencegahan HIV-AIDS di SMK Korpri Majalengka".

\section{Metode}

Penelitian ini menggunakan jenis penelitian pre-experiment dengan pendekatan one group pretest-posttest design.

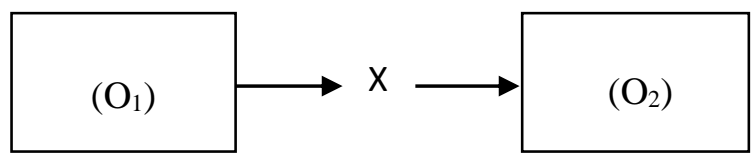

$\mathrm{O} 1=$ Pretest $($ sebelum perlakuan)

$\mathrm{X}=$ Perlakuan (peer education)

$\mathrm{O} 2=$ Posttest (sesudah perlakuan)

Populasi dalam penelitian ini adalah siswa kelas I di SMK Korpri Majalengka sebanyak 503 orang dan sampel sebanyak
Ciptaan disebarluaskan di bawah Lisensi Creative Commons AtribusiNonKomersial-BerbagiSerupa 4.0 Internasional.

83 orang dengan sistem random sampling. Analisis univariat dengan menggunakan distribusi frekuensi dan analisis bivariat dengan uji t.

Langkah pertama dalam proses pengumpulan data ini adalah peneliti berkoordinasi dengan guru BK dan Wakil Kepala Sekolah Kesiswaan tentang maksud dan tujuan teknik peer education ini. Kemudian dilakukan pemilihan educator yang dipandang layak mempunyai kemampuan dalam berkomunikasi dan dapat memengaruhi teman-temannya, setelah ditentukan orangnya, kemudian peneliti dan Guru Wakil Kepala Sekolah Kesiswaan memberikan pembekalan dan pengarahan pada educator. Peneliti memberikan materi tentang HIV/AIDS sampai educator faham, setelah dianggap menguasai mengenai bahan atau materi yang akan dibahas pada kegiatan pendidikan sebaya. Langkah berikutnya adalah menyiapkan kelas dan mengumpulkan responden, sebelumnya responden diarahkan untuk mengisi informed concent lalu diberikan kuesioner pretest pengetahuan dan sikap remaja terhadap HIV/AIDS. Setelah selesai mengisi dan menjawab kuesioner dalam pretest, kemudian educator memberikan pendidikan kesehatan tentang HIV/AIDS dengan model peer education selama 2 jam sekaligus tanya jawab bila ada responden yang kurang mengerti. Setelah itu responden diminta untuk mengisi dan menjawab kembali kuesioner posttest.

\section{Hasil dan Pembahasan}

Tabel 1. Distribusi Frekuensi Responden Berdasarkan Jenis Kelamin

\begin{tabular}{cccc}
\hline No & Jenis Kelamin & $\begin{array}{c}\text { Frekuensi } \\
\text { (f) }\end{array}$ & $\begin{array}{c}\text { Persentase } \\
(\%)\end{array}$ \\
\hline 1 & Laki-laki & 55 & 66,2 \\
2 & Perempuan & 28 & 33,7 \\
\hline & Jumlah & 83 & 100.0 \\
\hline
\end{tabular}

Berdasarkan hasil penelitian menunjukkan bahwa lebih dari setengah responden berjenis kelamin laki-laki sebanyak $(66,2 \%)$ 
Tabel 2. Distribusi Frekuensi Responden Berdasarkan Usia

\begin{tabular}{cccc}
\hline No & Usia & $\begin{array}{r}\text { Frekuensi } \\
(\mathrm{f})\end{array}$ & $\begin{array}{c}\text { Persentase } \\
(\%)\end{array}$ \\
\hline 1 & 16 tahun & 46 & 55,4 \\
2 & 17 tahun & 37 & 44,5 \\
\hline & Jumlah & 83 & 100.0 \\
\hline
\end{tabular}

Berdasarkan hasil penelitian menunjukkan bahwa lebih dari setengah

responden berusia 16 tahun sebanyak $(55,4 \%)$

Tabel 3. Distribusi Frekuensi berdasarkan Pengetahuan Remaja Tentang Pencegahan HIV-AIDS Sebelum Peer Education

\begin{tabular}{cccc}
\hline No & $\begin{array}{c}\text { Pengetahuan Remaja Tentang } \\
\text { Pencegahan HIV-AIDS } \\
\text { Sebelum Peer Education }\end{array}$ & $\begin{array}{c}\text { Frekuensi } \\
(\mathrm{f})\end{array}$ & $\begin{array}{c}\text { Persentase } \\
(\%)\end{array}$ \\
\hline 1 & Kurang & 17 & 20.5 \\
2 & Cukup & 50 & 60.2 \\
3 & Baik & 16 & 19.3 \\
\hline & Jumlah & 83 & 100.0 \\
\hline
\end{tabular}

Berdasarkan hasil penelitian menunjukkan bahwa responden di lebih dari setengahnya sebanyak $(60,2 \%)$ responden di SMK Korpri Majalengka sebelum peer education berpengetahuan cukup.

Tabel 4. Distribusi Frekuensi berdasarkan Pengetahuan Remaja Tentang Pencegahan HIV-AIDS Sesudah Peer Education

\begin{tabular}{|c|c|c|c|}
\hline No & $\begin{array}{c}\text { Pengetahuan Remaja Tentang } \\
\text { Pencegahan HIV-AIDS Sesudah } \\
\text { Peer Education }\end{array}$ & $\begin{array}{l}\text { Frekuensi } \\
\text { (f) }\end{array}$ & $\begin{array}{c}\text { Persentase } \\
(\%)\end{array}$ \\
\hline 1 & Kurang & 1 & 1.2 \\
\hline 2 & Cukup & 31 & 37.3 \\
\hline \multirow[t]{2}{*}{3} & Baik & 51 & 61.4 \\
\hline & Jumlah & 83 & 100.0 \\
\hline
\end{tabular}

Tabel 5. Distribusi Frekuensi berdasarkan Sikap Remaja Tentang Pencegahan HIVAIDS Sebelum Peer Education

\begin{tabular}{llcc}
\hline No & \multicolumn{1}{c}{$\begin{array}{c}\text { Sikap Remaja Tentang } \\
\text { Pencegahan HIV-AIDS Sebelum } \\
\text { Peer Education }\end{array}$} & $\begin{array}{c}\text { Frekuensi } \\
\text { (f) }\end{array}$ & $\begin{array}{c}\text { Persentase } \\
(\%)\end{array}$ \\
\hline 1 & Negatif & 47 & 56.6 \\
2 & Positif & 36 & 43.4 \\
\hline
\end{tabular}




\begin{tabular}{rrr}
\hline Jumlah & 83 & 100.0 \\
\hline
\end{tabular}

Berdasarkan hasil penelitian Korpri Majalengka sebelum peer education menunjukkan bahwa lebih dari setengahnya sebanyak $(56,6 \%)$ responden di SMK

Tabel 6. Distribusi Frekuensi berdasarkan Sikap Remaja Tentang Pencegahan HIVAIDS Sesudah Peer Education

\begin{tabular}{|c|c|c|c|}
\hline No & $\begin{array}{c}\text { Sikap Remaja Tentang } \\
\text { Pencegahan HIV-AIDS Sesudah } \\
\text { Peer Education }\end{array}$ & $\begin{array}{l}\text { Frekuensi } \\
\text { (f) }\end{array}$ & $\begin{array}{c}\text { Persentase } \\
(\%)\end{array}$ \\
\hline 1 & Negatif & 37 & 44.6 \\
\hline \multirow[t]{2}{*}{2} & Positif & 46 & 55.4 \\
\hline & Jumlah & 83 & 100.0 \\
\hline
\end{tabular}

Berdasarkan hasil penelitian menunjukkan bahwa lebih dari setengahnya sebanyak $(55,4 \%)$ responden di SMK
Korpri sesudah peer education bersikap positif.

Tabel 7. Pengaruh Peer Education terhadap Pengetahuan Remaja tentang Pencegahan HIV-AIDS

\begin{tabular}{ccccc}
\hline Variabel & Mean & SD & T & pvalue \\
\hline Pengetahuan (Pretest) & 19.35 & 3.412 & \multirow{2}{*}{10.986} & \multirow{2}{*}{0,0001} \\
Pengetahuan (Postest) & 23.20 & 2.749 & & \\
\hline
\end{tabular}

Berdasarkan hasil pengolahan statistik menunjukkan bahwa pengetahuan responden di SMK Korpri Majalengka sebelum peer education (pretest) diperoleh rata-rata sebesar 19,35 dan pengetahuan responden sesudah peer education (postest) diperoleh rata-rata sebesar 23,20 Sehingga diperoleh selisih rata-rata pretest-postest pengetahuan remaja tentang pencegahan
HIV-AIDS sebesar 3.85. Menurut hasil penghitungan statistik dengan paired sample t-test diperoleh t-value $=10,986$ dan $\rho$ value $=0,0001$ yang berarti $\rho$ value $<\alpha$, sehingga terdapat pengaruh signifikan peer education terhadap pengetahuan remaja tentang pencegahan HIV-AIDS.

Tabel 8. Pengaruh Peer Education terhadap Sikap Remaja tentang Pencegahan HIVAIDS

\begin{tabular}{ccccc}
\hline Variabel & Mean & SD & T & pvalue \\
\hline Sikap (Pretest) & 24.19 & 2.634 & \multirow{2}{*}{12.591} & \multirow{2}{*}{0,0001} \\
Sikap (Postest) & 28.58 & 3.562 & & \\
\hline
\end{tabular}

Berdasarkan hasil pengolahan statistik menunjukkan bahwa sikap responden di SMK Korpri Majalengka sebelum peer education (pretest) diperoleh rata-rata sebesar 24,19 dan sikap responden sesudah peer education (postest) diperoleh 
JURNAL ILMU KESEHATAN BHAKTI HUSADA:

HeALth SCIENCES JouRnal, Vol. 10 No. 02, DeSEMBer 2019 DOI: $10.34305 / J I K B H . V 10 I 2.93$

rata-rata sebesar 28,58. Sehingga diperoleh selisih rata-rata pretest-postest sikap remaja tentang pencegahan HIV-AIDS sebesar 4.39. Menurut hasil penghitungan statistik dengan paired sample t-test diperoleh $\mathrm{t}$ value $=12.591$ dan $\rho$ value $=0,0001$ yang berarti $\rho$ value $<\alpha$, sehingga terdapat pengaruh signifikan peer education terhadap sikap remaja tentang pencegahan HIV-AIDS.

Gambaran Pengetahuan Remaja Tentang Pencegahan HIV-AIDS Sebelum dan Sesudah Peer Education

Berdasarkan hasil penelitian menunjukkan bahwa lebih dari setengahnya $(60,2 \%)$ responden di SMK Korpri Majalengka sebelum peer education berpengetahuan cukup dan lebih dari setengahnya $(61,4 \%)$ responden di SMK Korpri Majalengka Kabupaten Majalengka tahun 2018 sesudah peer education berpengetahuan baik. Hal ini menunjukkan bahwa ada perubahan pengetahuan yang positif setelah diberi perlakuan peer education.

SMK Korpri merupakan sekolah swasta favorit di Kabupaten Majalengka dengan jumlah siswa yang cukup banyak hampir siswa berjumlah 1.642 jiwa lebih untuk semua tingkatan dan lebih dari setengahnya adalah laki-laki (66\%). Banyaknya siswa yang ada di SMK Korpri dengan latar belakang yang berbeda sehingga salah satu masalah yang sering dihadapi oleh pihak sekolah dan guru-guru di SMK Korpri adalah masalah kenakalan remaja. Banyaknya siswa menjadi salah satu faktor sulitnya melakukan pengontrolan dan pengawasan yang ketat pada semua siswa termasuk upaya sekolah mencegah siswanya terjerumus pada pergaulan bebas yang dapat berisiko terhadap penularan HIV/AIDS. Sehingga perlu adanya metode untuk meningkatkan pengetahuan dan sikap remaja agar mereka mempunyai perilaku pencegahan yang baik. Pengetahuan remaja setelah diberikan pendidikan kesehatan dengan metode peer education ternyata dapat meningkatkan pengetahuan remaja tentang pencegahan HIV/AIDS. Pada saat pretest masih terdapat 17 orang (20,5\%) berpengetahuan kurang namun setelah diberikan pendidikan kesehatan dengan metode peer education ternyata ditemukan hanya 1 orang $(1,2 \%)$ yang berpengetahuan kurang saat postest dikarenakan masih belum paham. Keberhasilan peer education dapat dipengaruhi oleh beberapa hal diantaranya yaitu persiapan yang matang, suasana dan tempat yang nyaman, serta pemilihan atau penunjukan educator dari kalangan remaja yang tepat. Kondisi yang mendukung tersebut menjadi perhatian dan pertimbangan peneliti agar pelaksanaan peer education dapat berlangsung sesuai dengan harapan.

Pengetahuan merupakan hasil mengingat suatu hal, termasuk mengingat kembali kejadian yang pernah dialami baik secara sengaja maupun tidak sengaja dan ini terjadi setelah orang melakukan kontak atau pengamatan terhadap suatu obyek tertentu. Hal ini menunjukkan bahwa sesuatu yang pernah dialami dalam hal ini termasuk proses transfer ilmu dalam kegiatan peer education dapat menjadi suatu hal yang akan diingat dan menjadi suatu pengetahuan bagi seseorang remaja dalam jangka pendek dan menghasilkan tindakan yang positif di kemudian hari (Notoadmodjo, 2012), (Mubarok, 2013). Keberhasilan dalam pelaksanaan peer education perlu memperhatikan kondisi ruangan yang nyaman dan lingkungan tidak gaduh, persiapan dari educator seperti memahami dan menguasai kelas, serta alat pendukung yang dapat memudahkan peserta memahami dan mencerna materi yang didiskusikan. Kondisi tersebut berusaha peneliti bangun dan dibantu oleh guru yang berwenang agar pelaksanaan peer education berjalan dengan baik (Notoadmodjo, 2012).

Pengetahuan adalah hasil dari tahu, dan terjadi setelah orang melakukan penginderaan terhadap suatu objek tertentu. Penginderaan itu terjadi melalui panca indera manusia yakni indera penglihatan, 
JURNAL ILMU KESEHATAN BHAKTI HUSADA:

HeALth SCIENCES JouRnal, Vol. 10 No. 02, DeSEMBer 2019 DOI: $10.34305 / J I K B H . V 10 I 2.93$

pendengaran, penciuman, rasa dan raba. Sebagian besar penginderaan manusia diperoleh melalui mata dan telinga. Pengetahuan kognitif merupakan domain yang sangat penting dalam membentuk tindakan seseorang (overt behavior). Berdasarkan hal tersebut setiap peserta berusaha untuk mendengar dan mencermati perkembangan diskusi yang dikembangkan oleh seorang educator yang telah menguasai kelas. Namun, ada juga peserta dengan kondisi yang kurang baik mempunyai masalah pribadi dapat mempengaruhi informasi tidak dapat dicerna dengan baik (Notoadmodjo, 2012).

Hasil penelitian ini sejalan dengan penelitian (Adeomi AA, Adeoye OA, Asekun-Olarinmoye EO \& OlugbengaBello AI, 2014) yang menyebutkan bahwa metode peer education dapat meningkatkan pengetahuan remaja dengan hasil p-value $<0,05$. Metode peer education mempunyai kelebihan tersendiri bagi remaja yang ikut didalamnya karena peserta dan pemberi materi dari kalangan remaja itu sendiri. Kebebasan dan keterbukaan perlu menjadi kunci didalam kegiatan pendidikan kesehatan bagi kalangan remaja agar mereka tertarik dan pengetahuannya semakin bertambah baik. Pelaksanaan dan evaluasi program pendidikan dan dukungan sebaya di sekolah menengah untuk mencegah dan mengurangi perilaku seksual berisiko tinggi di kalangan remaja dan untuk memberikan informasi yang akurat tentang HIV/AIDS, mendiskusikan dan mempertimbangkan kembali norma-norma kelompok sebaya, dan membangun dukungan untuk remaja (Visser MJ, 2007). Maka dari itu upaya yang dapat dilakukan oleh pihak sekolah adalah mengoptimalkan peran Organisasi Siswa Intra Sekolah (OSIS) untuk mengadakan diskusi sebaya yang dibimbing oleh guru Bimbingan dan Konseling (BK) serta memanfaatkan mading untuk menyebarkan informasi tentang pencegahan HIV-AIDS
Ciptaan disebarluaskan di bawah

Lisensi Creative Commons Atribusi-

NonKomersial-BerbagiSerupa 4.0

Internasional

1. Gambaran Sikap Remaja Tentang Pencegahan HIV-AIDS Sebelum dan Sesudah Peer Education

Berdasarkan hasil penelitian menunjukkan bahwa lebih dari setengahnya (56,6\%) responden di SMK Korpri Majalengka Kabupaten Majalengka tahun 2018 sebelum peer education bersikap negatif dan lebih dari setengahnya $(55,4 \%)$ responden sesudah peer education bersikap positif. Melalui peer education, sikap remaja dalam pencegahan HIV/AIDS dapat mengalami perubahan. Hal ini dikarenakan peer education merupakan salah satu bentuk pendidikan kesehatan yang efektif bagi kalangan remaja. Suasana bebas dan terbuka diantara mereka menjadi daya tarik tersendiri bagi remaja yang ikut dalam kegiatan tersebut.

Sikap adalah reaksi atau respon seseorang yang masih tertutup terhadap suatu stimulasi atau objek (Notoadmodjo, 2012). Sikap adalah perbuatan yang didasari oleh keyakinan berdasarkan normanorma yang ada di masyarakat dan biasanya norma agama. Namun demikian perbuatan yang akan dilakukan manusia biasanya tergantung pada apa permasalahannya serta benar-benar berdasarkan keyakinan atau kepercayaannya masing-masing (Maulana, 2013). Meskipun perubahan sikap tidak drastis terjadi pada saat itu juga, karena peer education hanya sebuah wadah atau sarana yang digunakan agar terjadi proses atau progres seseorang ke arah yang lebih baik sehingga perubahan itu akan terjadi pada hari-hari yang akan datang bisa positif maupun negatif. Pendidikan sebaya telah digunakan di berbagai bidang kesehatan publik, termasuk pendidikan gizi, keluarga berencana, penggunaan narkoba, dan pencegahan kekerasan dalam masyarakat. Namun, pendidikan sebaya dalam HIVAIDS menonjol karena penggunaannya sering diaplikasikan dalam kesehatan masyarakat internasional baru-baru ini (Suliswati, 2014). Oleh karena itu, upaya global dalam penggunaan peer education lebih diupayakan untuk memahami dan meningkatkan proses dan dampak peer 
JURNAL ILMU KESEHATAN BHAKTI HUSADA:

HeALth SCIENCES JouRnal, Vol. 10 No. 02, DeSEMBer 2019 DOI: $10.34305 / J I K B H . V 10 I 2.93$

education itu sendiri di bidang pencegahan, perawatan, dan dukungan HIV-AIDS.

Hasil penelitian ini sejalan dengan penelitian (Ghifari Andini Mukti, 2018) bahwa metode peer education dapat meningkatkan sikap siswa dengan hasil $p$ value <0,05. Peer education perlu dikembangkan karena dapat merubah sikap remaja yang awalnya negatif menjadi positif. Upaya yang dapat dilakukan oleh pihak sekolah adalah dengan cara membentuk kegiatan seminar atau diskusi remaja serta membentuk kelompok peer education dengan melibatkan OSIS yang ada di sekolah. Bagi guru juga dapat menjadikan model peer education sebagai salah satu alternatif dalam kegiatan pembelajaran di kelas untuk mendikusikan tentang pencegahan HIV-AIDS.

2. Pengaruh Peer Education terhadap Pengetahuan Remaja tentang Pencegahan HIV-AIDS

Berdasarkan hasil penelitian menunjukkan bahwa terdapat pengaruh peer education terhadap pengetahuan remaja tentang pencegahan HIV-AIDS di SMK Korpri Majalengka Kabupaten Majalengka Tahun 2018 ( $\rho$ value $=0,000$ ). Pengetahuan responden di SMK Korpri Majalengka Kabupaten Majalengka tahun 2018 sebelum peer education (pretest) diperoleh rata-rata sebesar 19,35 dan pengetahuan responden sesudah peer education (postest) diperoleh rata-rata sebesar 23,20 sehingga diperoleh selisih sebesar 3.85. Hal ini terjadi karena remaja sudah mengetahui tentang HIV/AIDS setelah diberi peer education.

Liliweri (2014) menyatakan bahwa salah satu pendekatan pendidikan kesehatan yang efektif pada remaja untuk mencegah maraknya kasus HIV/AIDS yaitu dengan metode Peer Education (pendidikan sebaya) (Liliweri, 2015). Pendidikan kelompok sebaya dilaksanakan antar kelompok sebaya tersebut dengan dipandu oleh fasilitator yang juga berasal dari kelompok itu sendiri. Melalui pendidikan sebaya kaum muda, dapat mengembangkan pesan maupun memilih media yang lebih
Ciptaan disebarluaskan di bawah Lisensi Creative Commons AtribusiNonKomersial-BerbagiSerupa 4.0 Internasional.

tepat sehingga informasi yang diterima dapat dimengerti oleh sesama mereka. Pendidikan paling efektif dalam pencegahan HIV/AIDS adalah melalui pendidikan sebaya karena kaum muda dapat mengembangkan pesan maupun memilih media yang lebih tepat sehingga informasi yang diterima dapat dimengerti oleh sesama mereka (Dita, 2013). Kelebihan metode ini salah satunya yaitu kebebasan remaja untuk mengemukakan pendapatnya dan dapat menjembatani kesenjangan antara informasi dan tingkah laku kesehatan dan pendidikan kesehatan sehingga memotivasi seseorang untuk menerima informasi kesehatan serta berbuat sesuai dengan informasi tersebut agar mereka menjadi lebih tahu dan lebih sehat.

Hasil penelitian ini sejalan dengan penelitian (Ghebreyohans G, Awad Gasim Khalilb E, Tsige Z, n.d.) bahwa peer education dapat meningkatkan pengetahuan dan sikap remaja secara signifikan dengan p-value $<0,05$. Juga hasil penelitian (Intan.Y, 2013) mengenai pengaruh metode peer education terhadap peningkatan pengetahuan dan sikap remaja tentang HIV/AIDS di SMAN 1 Geyer Kabupaten Grobogan menyatakan bahwa ada pengaruh yang positif metode peer education terhadap peningkatan pengetahuan remaja tentang HIV/AIDS (Intan.Y, 2013).

Peer education dapat meningkatkan pengetahuan remaja secara efektif karena kondisi diskusi yang terbuka di kalangan remaja mendukung terhadap pembicaraan dan tanya jawab menjadi lebih luas sehingga wawasan remaja yang awalnya tidak tahu menjadi tahu dan lebih memahami.

4. Pengaruh Peer Education terhadap Sikap Remaja tentang Pencegahan HIV-AIDS

Berdasarkan hasil penelitian menunjukkan bahwa terdapat pengaruh peer education terhadap sikap remaja tentang pencegahan HIV-AIDS di SMK Korpri Majalengka Kabupaten Majalengka Tahun 2018 ( $\rho$ value $=0,000)$. Sikap responden di SMK Korpri Majalengka 
JURNAL ILMU KESEHATAN BHAKTI HUSADA:

HeALth SCIENCES JouRnal, Vol. 10 No. 02, DeSEMBer 2019 DOI: $10.34305 / J I K B H . V 10 I 2.93$

Kabupaten Majalengka tahun 2018 sebelum peer education (pretest) diperoleh rata-rata sebesar 24,19 dan sikap responden sesudah peer education (postest) diperoleh rata-rata sebesar 28,58 sehingga diperoleh selisih sebesar 4.39. Hal ini terjadi kemungkinan setelah pengetahuan remaja meningkat akan melahirkan suatu sikap yang baik pula.

Sikap merupakan perbuatan yang didasari oleh keyakinan berdasarkan normanorma yang ada di masyarakat dan biasanya norma agama. Namun perbuatan yang akan dilakukan manusia biasanya tergantung pada apa permasalahannya serta benarbenar berdasarkan keyakinan atau kepercayaannya masing-masing (Maulana, 2013). Pelaksanaan dan evaluasi peer education mendukung program di sekolah menengah untuk mencegah dan mengurangi risiko tinggi perilaku seksual di kalangan remaja. Sikap seseorang tidak dapat berubah begitu saja tanpa ada proses yang mendasarinya. Melalui peer education akan terjadi proses perubahan cara berfikir seseorang karena terjadi dialog atau diskusi terbuka untuk mengeluarkan pendapatnya masing-masing. Selain itu melalui penyebaran informasi dan pendidikan kesehatan tentang HIV/AIDS pada remaja terbukti efektif dalam meningkatkan pengetahuan serta mempengaruhi sikap remaja berisiko terhadap terjangkitnya oleh virus HIV/AIDS (Mozes, 2014).

Hasil penelitian ini sejalan dengan penelitian (Abbaspour Z, Saidian M, 2007) ada pengaruh peer education atau pendidikan sebaya terhadap sikap mahasiswa dalam menanggulangi HIV/ AIDS dengan $p$-value $<0,05$. Untuk membangun sikap dan nilai positif di kalangan remaja dalam pencegahan HIV/AIDS perlu adanya sautu metode yang efektif dan salah satunya dapat menggunakan metode peer education, karena diskusi di kalangan remaja dan oleh remaja lebih tebuka sehingga akan menghasilkan komunikasi yang aktif di kalangan remaja. Sikap yang didasari oleh pengetahuan akan menghasilkan tindakan yang dapat bersifat langgeng. Maka dari itu,
Ciptaan disebarluaskan di bawah Lisensi Creative Commons AtribusiNonKomersial-BerbagiSerupa 4.0 Internasional.

perlunya pihak sekolah mengoptimalkan peran OSIS untuk mengadakan seminar, diskusi remaja tentang pencegahan HIV/AIDS dan perlunya memanfaatkan mading untuk penyebarluasan informasi kepada remaja tentang pencegahan HIV/AIDS.

\section{Simpulan}

1. Lebih dari setengahnya remaja sebelum peer education berpengetahuan cukup dan lebih dari setengahnya sesudah peer education berpengetahuan baik.

2. Lebih dari setengahnya remaja sebelum peer education bersikap negatif dan lebih dari setengahnya remaja sesudah peer education bersikap positif.

3. Terdapat pengaruh peer education terhadap pengetahuan remaja tentang pencegahan HIV-AIDS.

\section{Daftar Pustaka}

Abbaspour Z, Saidian M, A. P. (2007). Peer education vs health provider education in knowledge and attitude about prevention and transmission of AIDS in high school students. Pakistan Journal Medical Science, 23(1), 108110.

Adeomi AA, Adeoye OA, AsekunOlarinmoye EO, A. O., \& OlugbengaBello AI, S. A. (2014). Evaluation of the effectiveness of peer education in improving HIV knowledge, attitude, and sexual behaviours among inschool adolescents in osun state, Nigeria. AIDS Res Treat.

Andrews, L. (2011). Hindari AIDS Demi Masa Depan Kita Semua. Medan: Monora.

Dewi, S. N. (2012). Pengaruh Pendidikan Kesehatan Terhadap Perubahan Pengetahuan dan Sikap Dalam Pencegahan HIV/AIDS Pada Pekerja Seks Komersial di Kabupaten Sumedang. Media Ners, 2.(1).

Dinas Kesehatan Kabupaten Majalengka. (2017). Profil Kesehatan Kabupaten Majalengka tahun 2016. 
JURNAL ILMU KESEHATAN BHAKTI HUSADA:

HeALth SCIENCES JouRnal, Vol. 10 No. 02, DeSEMBer 2019

DOI: $10.34305 / J I K B H . V 10 I 2.93$

Dita, S. (2013). Psikologi Anak, Remaja, dan Keluarga. Jakarta: Gunung Mulia.

Ghebreyohans G, Awad Gasim Khalilb E, Tsige Z, A. F. (n.d.). The Effect of Peer Education on Peer Educators' Reproductive Health Knowledge, Attitude, Health Service use and their Personal Development. International Science, 453(1), 294-312.

Ghifari Andini Mukti. (2018). Pengaruh Peer Education terhadap Pengetahuan dan Sikap Remaja tentang HIV/AIDS di SMAN 1 Kretek Bantul. Jurnal Poltekes Kemenkes Yogyakarta. Retrieved from http://eprints.poltekkesjogja.ac.id/

Harahap, J. dan A. (2014). Pengaruh Peer Education Terhadap Peningkatan Pengetahuan dan Sikap Mahasiswa Dalam Menanggulangi HIV/ AIDS di Sumatera Utara. Universitas Sumatera Utara.

Hidayat, A. (2012). Pengantar Ilmu Kesehatan Anak Untuk Pendidikan Kebidanan. Jakarta: Salemba Medika.

Intan.Y. (2013). Pengaruh Metode Peer Education terhadap Peningkatan Pengetahuan dan Sikap Remaja tentang HIV/AIDS di SMAN 1 Geyer Kabupaten Grobogan tahun 2013. Jurnal Kebidanan, 3.

Kemenkes RI. (2018). Profil Kesehatan Indonesia Tahun 2017. Jakarta: Kemenkes RI.

Kementerian Kesehatan RI. (2017). Profil Kesehatan Indonesia Tahun 2016.
Ciptaan disebarluaskan di bawah

Lisensi Creative Commons Atribusi-

NonKomersial-BerbagiSerupa 4.0

Internasional

Jakarta.

Kusmiran, E. (2011). Reproduksi Remaja dan Wanita. Jakarta: Salemba Medika.

Liliweri, A. (2015). Komunikasi Kesehatan. Yogyakarta: Pustaka Pelajar.

Maulana. (2013). Promosi Kesehatan. Jakarta: Buku Kedokteran EGC.

Mozes, A. (2014). Remaja Merupakan Fokus dari Upaya Pencegahan AIDS. Retrieved from http://www.kesrepro.info

Mubarok. (2013). Psikologi Remaja,Petunjuk Bagi Guru dan orangtua. Bandung: Pustaka Setia.

Notoadmodjo, S. (2012). Pendidikan dan Perilaku Kesehatan. Jakarta: Rineka Cipta.

SMK Korpri Majalengka. (2017). Profil SMK Korpri Majalengka. Majalengka.

Suliswati, L. (2014). Pendidikan Kesehatatan HIV AIDS.

UNAIDS. (2012). Practical Guidelines for Intesifying HIV Prevention: Towards Universal Accsess- UNAIDS.

Visser MJ. (2007). HIV/AIDS Prevention Through Peer Education And Support In Secondary Schools In South Africa. Journal of Social Aspect of HIV/AIDS, 3(4), 678-694. Retrieved from http://www.up.ac.za/dspace/bitstream/ 2263/5418/1/Visser_HIV

World Health Organization. (2016). Juvenile Deliquency: Adolescence. Retrieved from www.who.int/research/en/ 